\title{
Malaysian and Italian trend line for Covid-19: A study on trend analysis
}

\author{
Wan Muhammad Amir Wan Ahmad 1*, Noor Azlinaliana Ibrahim ${ }^{1}$, Mohamad Arif \\ Awang Nawi1, Nor Farid Mohd Noor' ${ }^{1}$, Noraini Mohamad', Nor Azlida Aleng², Farah \\ Muna Mohamad Ghazali1, Nasar Um Min Allah3 \\ ${ }^{1}$ School of Dental Sciences, Health Campus, Universiti Sains Malaysia, 16150 Kubang Kerian, \\ Kota Bharu, Kelantan, Malaysia \\ ${ }^{2}$ Faculty of Ocean Engineering Technology and Informatics, Universiti Malaysia Terengganu, \\ 21030 Kuala Terengganu, Terengganu, Malaysia \\ ${ }^{3}$ Foundation University College of Dentistry and Hospital, Foundation University Islamabad, Pakistan
}

*Corresponding e-mail: wmamir@usm.my

ARTICLE INFO

Article History

Received 11 April 2021

Revised 5 September 2021

Accepted 28 October 2021

\section{Keywords}

Trend analysis;

Covid-19;

Quadratic trend;

Linear trend.

How to cite this article: Wan Ahmad, W. M. A., Ibrahim, N. A., Nawi, M. A. A., Mohd Noor, N. F., Mohamad N., Aleng, N. A., Ghazali, F. M. M., \& Min Allah, N. U. (2021). Malaysian and Italian trend line for Covid-19: A Study on trend analysis. Bulletin of Applied Mathematics and Mathematics Education, 1(2), 6174.

\section{ABSTRACT}

The first objective of this study was to evaluate trend line pattern obtain the appropriate statistical equation model, and predict individual numbers infected by Covid-19. The second objective is to obtain a predictive equation model and forecast death rate for Malaysia and Italy. Malaysia's first positive case Covid-19 recorded January 24, 2020, consisting of three cases. Collected from January 24 to March 29, 2020. Sixty-six day-observations, based on their trend line pattern, earned special attention. Although the first positive case was identified on January 31,2020 , involving two patients. From January 31 to March 29, 2020, approximately 59 observations were collected from Italy. On 18 March 2020, the pattern will contrast with the Malaysian Movement Control Order (MCO). Malaysia and Italy collect death figures. A similar methodology will be applied to find the best-fitted model that fits both countries' death-number scenario. In Italy, the number of Covid19-infected patients rises and meets quadratic trend line patterns. This induces extreme public distress and diversion. The quadratic trend line series analysed individual Covid-19-infected results. After March 18, 2020, it will continue to use a linear pattern. However, trend deaths also follow quadratic trend line pattern. Trend-line quadratic matched Italy's results. The quadratic line-of-trend model projection demonstrated dominance in estimating infected Covid-19. The quadratic death line from daily death collection data also showed superiority in estimating death number. The fitted quadratic model is better fitted in the Malaysian case, but the pattern shifts to linear trend line after MCO is implemented.

This is an open access article under the CC-BY-SA license.

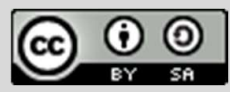

\section{Introduction}

Coronavirus disease 2019 (COVID-19) is a respiratory tract infection caused by a newly emergent coronavirus, SARS-CoV-2, that was first recognized in Wuhan, China, in December 2019 
(WHO, 2020a; Vital Surveillances, 2020). COVID-19 epidemic has spread very quickly taking only 30 days to expand from Hubei to the rest of Mainland China resulting in an epidemic throughout the China, followed by an increasing number of cases in other countries throughout the world (Vital Surveillances, 2020; WHO, 2020a).

The virus is released in the respiratory secretions when an infected person coughs, sneezes or talks. These droplets can infect others if they make direct contact with the mucous membranes. Infection can also occur by touching an infected surface and followed by touches his or her eyes, nose, or mouth. Droplets typically do not travel more than six feet (about two meters) and do not linger in the air (Joseph \& Ashkan, 2020; Zou et al., 2020). However, in one letter to the editor, SARS$\mathrm{CoV}-2$ remained viable in aerosols under experimental conditions for at least three hours (van Doremalen et al., 2020).

World Health Organization (WHO) has announced that COVID-19 reached the pandemic stage on 11 March 2020 in view of more than 118,000 cases of Covid-19 detected in 114 countries with 4,291 people have lost their lives till that date (WHO, 2020b). It was recommended that, the community needs to avoid crowded place, particularly in poorly ventilated spaces if possible and avoiding close contact with ill individuals and also try to maintain a safe distance of 1 meter in order to prevent the transmission of COVID-19 in the community (Joseph \& Ashkan, 2020). In response to prevent more new cases of COVID-19 detected in Malaysia, the Prime Minister of Malaysia was declared the movement control order on March 16 th, 2020 as an effort to deal with the rise in COVID-19 cases. Initially, the MCO order was started from $18^{\text {th }}$ to $31^{\text {st }}$ March 2020. The decision was made under the Prevention and Control of Infectious Diseases Act 1988 and the Police Act 1967 (Tang, 2020). However, the COVID-19 cases were increased tremendously from 790 total cases on the day 1 of MCO had implemented to 1796 cases on day 8 of MCO with 20 deaths. Therefore, the government have decided to extend the MCO until April 14th, 2020 on March 25th 2020 (Anis, 2020). Till this manuscript was written on March 29th, 2020, the total cases of patient were infected with COVID-19 in Malaysia was 2470 cases with 35 deaths (MOH, 2020a).

Italy is one of the European countries that was seriously affected by COVID-19 virus. The Prime Minister of Italy had announced the restrictions order over entire country on March $9^{\text {th }} 2020$ in attempt to halt coronavirus outbreak where 9,172 of their peoples had been infected by the virus with total deaths of 463 people on that date (Horowitz, 2020). However, after 21 days of the restriction order, on 29th March 2020, 97689 total cases of COVID-19 were identified with 10779 deaths (Worldometers, 2020a). Therefore, this analysis study was conducted to determine the Malaysian and Italy trend line for COVID-19 with and without movement control order (MCO).

\section{Method}

This study was conducted by reviewing the daily data (See Appendix 1) which published by 
Malaysia Ministry of Health starting from January 24th 2020 (with 3 infected cases) until March $29^{\text {th }}$ 2020 (with 2470 infected cases), while data from Italy was started collected at on January $31^{\text {th }} 2020$ (with 2 infected cases) until March 29th 2020 (with 97689 infected cases). Statistical analysis was performed by using SPSS and MINITAB software version 17 through trend line analysis. Trend analysis allows researcher to investigate the phenomenon of Covid-19 from the beginning. The first case study is referred to the Italy, daily data [starting from January 31st, 2020 until March 29th, 2020] from Italy were analyzed through the linear trend, quadratic trend, and exponential growth trend. In this case, the quadratic trend model is the most suitable method that can represent the trend for Covid-19 in Italy. After model selection, the projection of infection patients will be determined (Model I: Quadratic trend model for infected patients).

The second modelling is about the death analysis (Model II: Quadratic trend model for death patients). Similar to the step given in Model I, the projection of death trend also being summarize (See Figure 1). The second case is on Malaysia trend analysis for Covid-19. The most suitable pattern is being determined as like the step in the first case. There are two different models is being considered in this paper. First model (Model I) is based on the quadratic trend model, where the collected data is being fitted quadratically and tested according to the best model fitting. Then, the projection of each model is also being discussed, according to the obtaining model. For the second proposed model (Model II), to control the Covid-19 outbreak in Malaysia, the movement control order (MCO) was implemented on March 18 ${ }^{\text {th }}, 2020$. Therefore, data is being separated starting on 18 March 2020 and the specific observation will be given while analyzing this collected data. This scenario also gives an impact on the trend of Covid-19 outbreak in Malaysia after 14 days.

The daily data was collected which begin in March 18 ${ }^{\text {th }}, 2020$ till March 28 $8^{\text {th }}, 2020$ and is being studied through the trend line analysis. Linear trend analysis is found to be the most suitable for the case represent, then the forecasting of the linear trend of the Covid-19 outbreak will available prediction purposed. This is very important to determine the number of futures infected by Covid19. Malaysia has recorded first deaths from Covid-19 on March 7th, 2020. It is very important to estimate the number of deaths according to the number of infected patients. The number of deaths was recorded. The number of deaths getting increase slowly. Pattern searching shows that the bestfitting for death is a quadratic trend model instead of the linear trend line. A specific pattern of death will be capture through the plotting trend line analysis. This is very useful especially to prevent and educate the public on the important of good personal and family health care. A short projection from the obtaining model will make up to 5 days of periods. Table 1 summaries the number of infected and death in Malaysia and Italy from January 24th, 2020 till April 2nd, 2020. For the trend analysis and modelling purpose, the collected data up to March 29th, 2020 will be considered for the trend analysis. 


\section{Results and Discussion}

\section{Case I: Trend Analysis for Covid-19 for Italy}

Trend analysis for Covid-19 for infected patient in Italy from February 20th - March 29th 2020

The first confirmed case of COVID-19 in Italy was record on January 31st, 2020

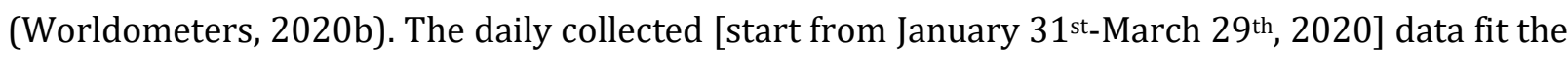
quadratic trend model. Figure 1 shows the trend is increasing drastically. One of the main factors which contribute to the rapid death in Italy was due to age factor, where Italy has the oldest population in Europe (about 23\% of population was 65 years and older). Many Italian deaths occurred between aged of 80-90 years old. In this Covid-19 outbreak, it is important to study the number of mortalities by pattern because it will give us a very clear picture of the number of deaths which has kept rising across the time. Figure 2 show the trend analysis. The best model that can represent the quadratic trend is given as follows.

$$
Y_{t}=6768-1942 \times t+109.88 \times t^{2}
$$

Figure 2 shows the quadratic trend model that represents the outbreak of Covid-19 in Italy. Begin with two registered patients on $31^{\text {st }}$ January 2020, the number of infected patients increased quadratically in response to a total infected by Covid-19. The trend line projection of infected Covid19 patients can be performed by using the equation (i). Therefore, the prediction number of infected by Covid-19 can be estimated. Using the equation (i) the projection number from a patient infected is being determined and summarized in Table 2.

The origin data was collected from January $31^{\text {st }}$ - March 29th 2020 . The projection shows the number of infected by Covid-19 up to April 7th, 2020. The infected case number is still increased, but this is not coming under control at this time point. To reduce, the number of infected by Covid19, public awareness needs to be increased to reduce the risk of infection and prevent the coronavirus from widespread.

Death Trend analysis for Covid-19 in Italy from January 31st - March 29th, 2020

The daily collected data [start from January 31 st - March 29th, 2020] fit the quadratic trend model. Figure 1 shows the trend analysis. The best model that can represent the fitted quadratic trend equation is given as follows.

$$
\mathrm{Y}_{\mathrm{t}}=1090-291.1 \times \mathrm{t}+14.038 \times \mathrm{t}^{2}
$$

The projection of death number is being made by using the equation (ii) up to April $7^{\text {th }}, 2020$. The predicted result of death cases numbers being listed in Table 1. 
Table 1. Projection number infected and prediction of number death by Covid-19 (Italy)

\begin{tabular}{ccc}
\hline Date & $\begin{array}{c}\text { Prediction number of an individual } \\
\text { infected by Covid-19 }\end{array}$ & $\begin{array}{c}\text { Prediction of death } \\
\text { by Covid-19 }\end{array}$ \\
\hline 30-Mar-2020 & 104896 & 11088 \\
31-Mar-2020 & 111854 & 11906 \\
01-Apr-2020 & 119032 & 12752 \\
02-Apr-2020 & 126430 & 13626 \\
03-Apr-2020 & 134047 & 14528 \\
04-Apr-2020 & 141884 & 15459 \\
05-Apr-2020 & 149941 & 16417 \\
06-Apr-2020 & 158218 & 17403 \\
07-Apr-2020 & 166714 & 18418 \\
\hline
\end{tabular}

The number of deaths in Italy seems to be downright scary. The trend can be well predicted through the quadratic model. The death cases are almost about one thousand a day. This situation creates discomfort and extreme fear among the Italian.

\section{Case II: Trend Analysis for Covid-19 for Malaysia}

Trend analysis for Covid-19 for infected patient in Malaysia from February 20th - March 29th, 2020

\section{Model I: Quadratic Trend Model}

The first confirmed case of COVID-19 in Italy was record on January 24th 2020 . The daily collected data was start on start from January 24th - March 29th 2020 . At first the data was fit using quadratic trend model. Figure 2 shows the trend is increasing smoothly, but not linearly. Preliminary investigation by the Ministry of Health Malaysia, found that most of the new findings are related to the religious ceremony held in Kuala Lumpur from February 27th, 2020 to March 1st, 2020 (Karim, 2020). Figure 3 show the quadratic trend analysis. The best model that can represent the quadratic trend is

$$
Y_{t}=111.2-34.45 \times t+2.861 \times t^{2}
$$

Table 2 shows the prediction of number infected by Covid-19 using equation (iii). From March 18 $8^{\text {th }}, 2020$ till April 4th 2020.

\section{Model II: Linear Trend Model}

At the second step, the data was being fit through the linear trend analysis. Figure 2 gives the plot and the fitted model. The fitted linear trend is given by

$$
\mathrm{Y}_{\mathrm{t}}=571.5+157.32 \times \mathrm{t}
$$


BAMME Vol. 1 No. 2, October 2021, pp. 61-74

Using the equation (iv) the projection number from a patient infected is being determined and summarized in Table 3. The real recorded data of the real number for the individual infected by Covid-19 from March 18th till April 4th 2020 was also shown in Table 2.

Table 2. Prediction of number infected by Covid-19 Using Model I and Model II, Prediction of number death by Covid-19 Using Model II, and Real Number of Individual infected by Covid-19

(Malaysia)

\begin{tabular}{|c|c|c|c|c|}
\hline \multirow[t]{2}{*}{ Date } & \multirow[b]{2}{*}{$\begin{array}{c}\text { Model I } \\
\text { Prediction of } \\
\text { individual } \\
\text { infected by } \\
\text { Covid-19 }\end{array}$} & \multicolumn{2}{|c|}{ Model II } & \multirow{2}{*}{$\begin{array}{c}\text { Real data } \\
\text { infected by } \\
\text { Covid-19 }\end{array}$} \\
\hline & & $\begin{array}{l}\text { Prediction of } \\
\text { individual } \\
\text { infected by } \\
\text { Covid-19 }\end{array}$ & $\begin{array}{c}\text { Prediction of } \\
\text { death number by } \\
\text { Covid-19 }\end{array}$ & \\
\hline 18-Mar-2020 & 649 & & & 790 \\
\hline 19-Mar-2020 & 738 & & & 900 \\
\hline 20-Mar-2020 & 832 & & & 1030 \\
\hline 21-Mar-2020 & 932 & & & 1183 \\
\hline 22-Mar-2020 & 1038 & & & 1306 \\
\hline 23-Mar-2020 & 1149 & & & 1518 \\
\hline 24-Mar-2020 & 1266 & & & 1624 \\
\hline 25-Mar-2020 & 1389 & & & 1796 \\
\hline 26-Mar-2020 & 1518 & & & 2031 \\
\hline 27-Mar-2020 & 1652 & & & 2161 \\
\hline 28-Mar-2020 & 1792 & & & 2320 \\
\hline 29-Mar-2020 & 1938 & & & 2470 \\
\hline 30-Mar-2020 & 2090 & 2616 & 37 & 2626 \\
\hline 31-Mar-2020 & 2247 & 2773 & 41 & 2766 \\
\hline 01-April-2020 & 2410 & 2931 & 46 & 2908 \\
\hline 02-April-2020 & 2578 & 3088 & 51 & 3116 \\
\hline 03-April-2020 & 2753 & 3245 & 56 & 3333 \\
\hline 04-April-2020 & 2933 & 3403 & 61 & 3483 \\
\hline 05-April-2020 & & 3560 & 66 & \\
\hline
\end{tabular}

Model I and Model II give the prediction according to the best fitting model. Model II is being fit using the data which starting on March 18 ${ }^{\text {th }}, 2020$ till March 28 $8^{\text {th }}, 2020$. The Man Whitney method was applied to know is there any significant difference in the data predicted data (From Model II) with the real collected data. Table 3 shows the result in detail.

Table 3. Mann-Whitney U test

\begin{tabular}{lcc}
\hline & Test Statistics $^{\mathrm{a}}$ & $p$-value \\
\cline { 2 - 3 } Mann-Whitney U & -0.731 & 0.465 \\
\hline
\end{tabular}

Table 3 shows that there is no significant different the predicted data [March 18 ${ }^{\text {th }}, 2020-$ April 5 $5^{\text {th }}, 2020$ ] with the real data [March 18 ${ }^{\text {th }}, 2020$ - April $\left.4^{\text {th }}, 2020\right]$. This indicates that the predicted data with the real data having no significant difference. 
Death Trend analysis for Covid-19 in Malaysia from March 17th, 2020 - March 29th, 2020

The daily collected [start from $17^{\text {th }}$ January - March $2^{\text {th }}, 2020$ ] data fit the quadratic trend model. Figure 1 show the trend analysis. The best model that can represent the fitted quadratic trend equation is

$$
Y_{t}=-1.30+1.341 \times t+0.1024 \times t^{2}
$$

Using the equation $(\mathrm{v})$, the projection number from a patient death is being determined and summarized in Table 2. The death number is still increased, but this is still coming under control. The numbers of deaths patients shown to increase slow after the implementation of MCO.

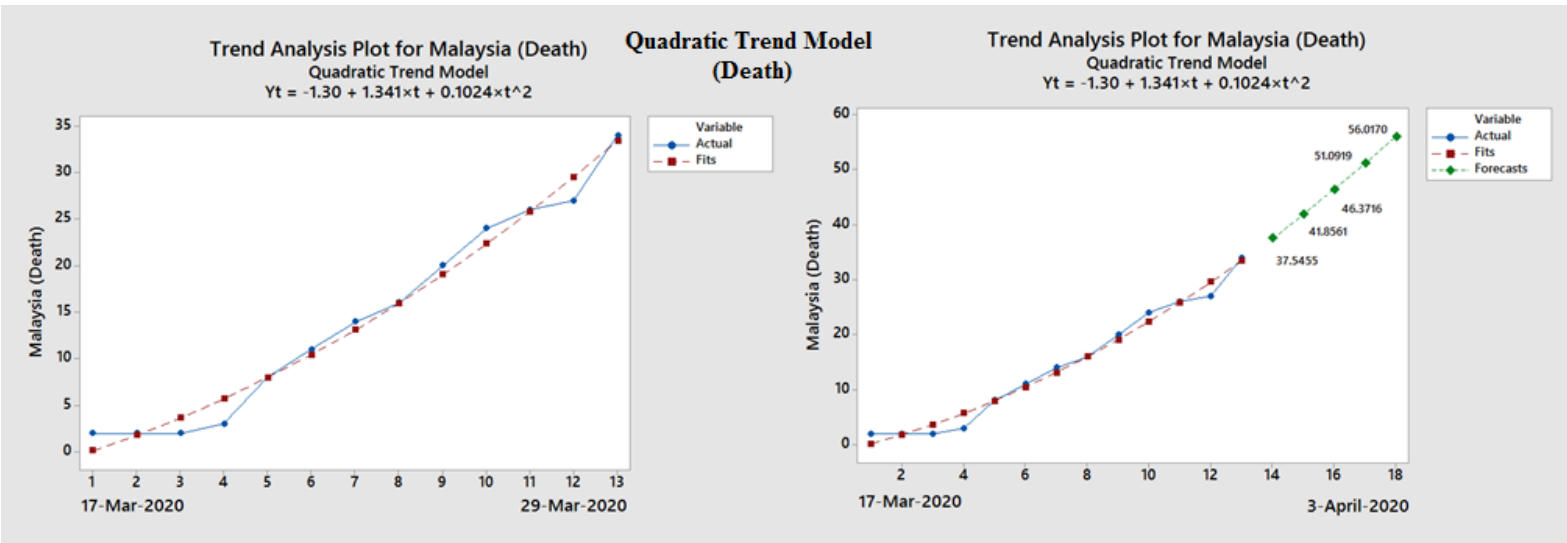

Figure 1. A Trend line analysis and projection for Covid-19 in Malaysia (Death number) March 17th, 2020 -March 29th 2020

Covid-19 is a disease caused by the infection with Severe Acute Respiratory Syndrome Coronavirus 2 (SARS-CoV2), from the family of Coronavirus. Covid-19 has a broad spectrum of clinical presentation, perhaps it may present as a very mild acute respiratory infection (ARI) in the form of sore throat, cough to very severe respiratory disease (SARI) in the form of pneumonia with fatal ARDS (Joseph \& Ashkan, 2020). March 16 th 2020, the Malaysian Prime Minister had announced MCO from March 18 $8^{\text {th }}$ until March 31 $1^{\text {st }}, 2020$ (Tang, 2020). The poor dissemination of instruction had led to the mass mobilization of the public, therefore, the MCO had been prolonged up to April 14th 2020 (Anis, 2020). This is to ensure the number of infected and the number of deaths is reduced. Patients with chronic respiratory conditions, chronic cardiac disease and chronic illnesses including diabetes mellitus, renal failure, immunosuppressed and adults with the age more than 65 years are at the higher risk when exposing to the COVID-19 (CDC, 2020). These scenarios are very downright scary, this infectious disease outbreak causing loss of life. Therefore, Malaysia through Universiti Sains Malaysia (USM) had published a guideline for the management of infectious disease outbreaks "Response and Readiness Plan for COVID-19 Pandemic and Other Infectious Diseases Outbreaks" (MOH, 2020b). 


\section{Case I: Trend analysis for Covid-19 for Italy}

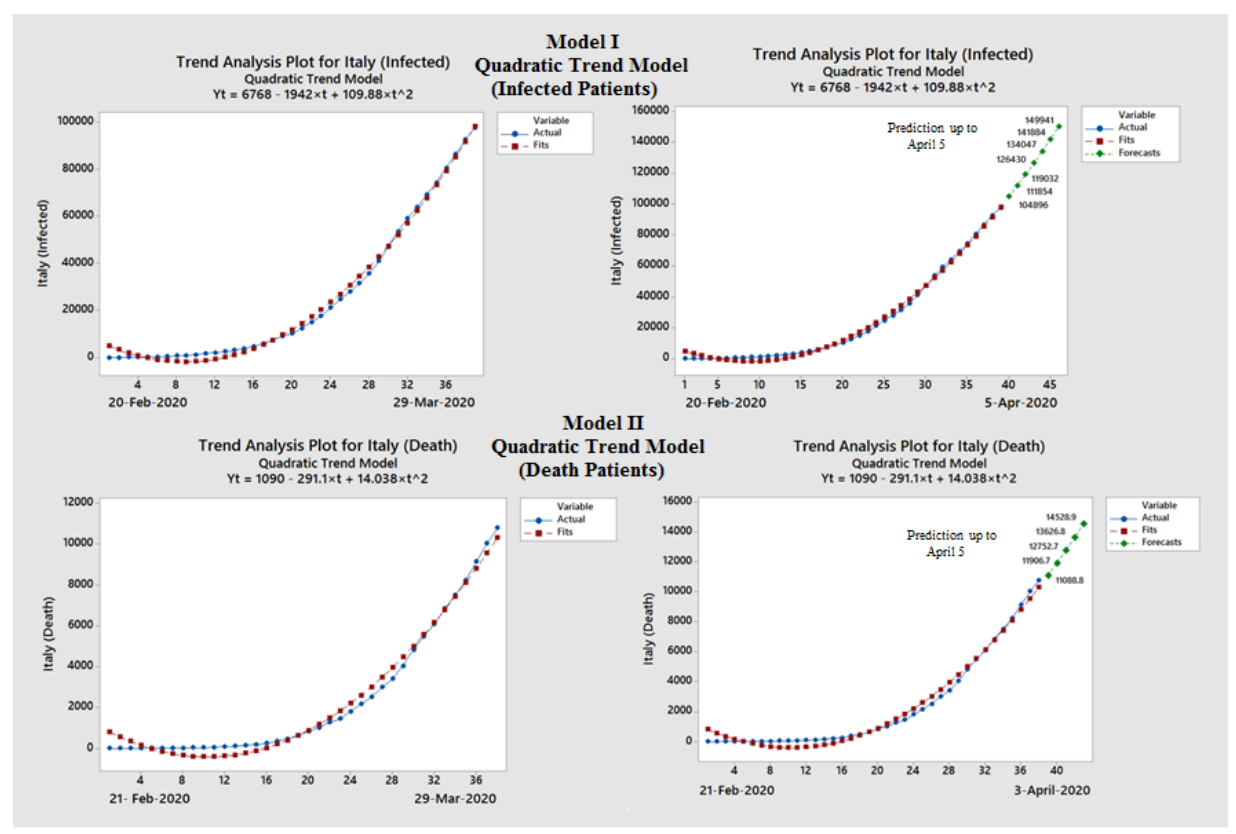

Figure 2. A Trend line analysis and projection for Covid-19 in Italy February $21^{\text {st }}, 2020$ - April $3^{\text {rd }} 2020$

\section{Case II: Trend analysis for Covid-19 for Malaysia}

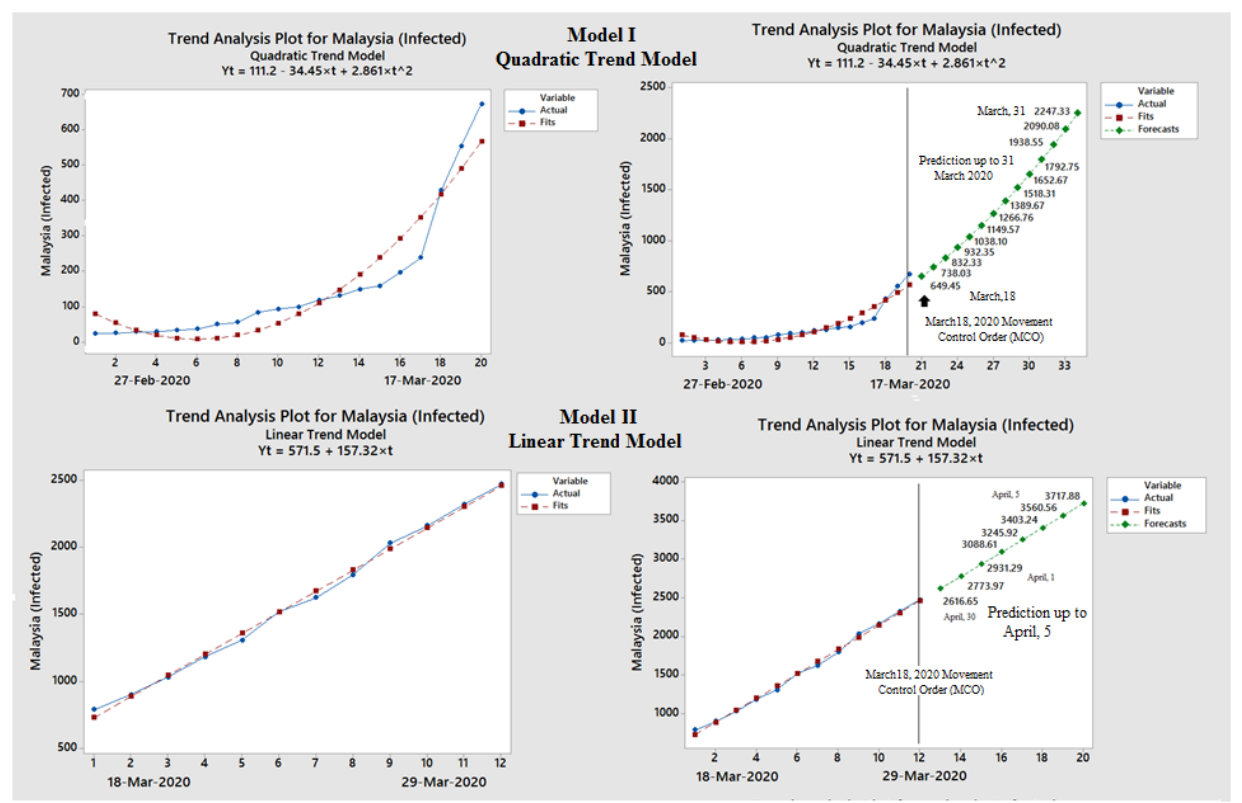

Figure 3. A Trend line analysis and projection for Covid-19 in Malaysia February 27th, $2020-$ April $5^{\text {th }} 2020$

One of the most important things that countries are doing to help understand and stop the spread of COVID-19 is by giving awareness and a good understanding of the basic information about coronavirus disease (COVID-19). According to the trend of Italy, it begins with the quadratic 
increase, but if the data being to prolong the quadratic modelling is no longer suitable, but the exponential model will more suitable. After the United States of America, Italy currently has the second-largest number of COVID-19 incidents and has a very high fatality rate (WHO, 2020c). Thousands of individuals infected, and hundreds of deaths being recorded in a day, and this trend is increasing over time, this indicates this pandemic needs to be solved immediately and, immediate action also needs by the Italian government to prevent this outbreak from becoming worst. In this study, we found that the trend analysis for COVID-19 for the infected patients in Italy is best presented using a quadratic trend model, whereas Malaysia bests presented using linear trend analysis.

In Malaysia, Covid-19 was first reported in Malaysia on $2^{\text {nd }}$ January 2020. The first wave ends on $17^{\text {th }}$ February with only 22 cases. Malaysia started to record new cases starting on February $27^{\text {th }}$, 2020 , and escalated day by day. However, the trend seems to be increased over time. On March $18^{\text {th }}$, 2020, the total number of confirmed cases in Malaysia was recorded with 790 cases including two deaths. Interestingly the number of cases in Malaysia lower than Italy, which indicates the impact could be due to the fast actions by the Malaysian government to tackle COVID-19 situation. The decision for implementation of MCO was made on the $16^{\text {th }}$ of March 2020 when the total number of 553 infected cases recorded with zero deaths (See Appendix 1) (Tang, 2020). The Malaysian government announced MCO started from $18^{\text {th }}$ March until the $31^{\text {st }}$ of March 2020. Based on the daily increasing number of infected cases reported, the Malaysian government once again announced the extension of MCO up to the $14^{\text {th }}$ of April 2020 (Anis, 2020). At the earliest of MCO, it has poor widespread dissemination of instruction, which had led to the mass mobilization of the general public. The trend of infected can be seen clearly in Figure 3, having a slow, steady increase in numbers, it has shown the signs of early success in efforts to control and flatten the curve of the Covid-19 pandemic. At the beginning of the second MCO, showed that the number of cases increased but in flatten the trend. Other than that, the Malaysian government also improve its strategy and activities by identifying hotspots during the second phase of the MCO, control the movement of the public.

The most challenging forecast of the COVID-19 scenario is the estimated number of infected patients to be reached in Malaysia. This prediction is very important in predicting the number of infected cases in Malaysia to plan new healthcare facilities and to measure the amount of time in which they will be usable. Because of the Malaysian population is half that of Italy (about 32 million in Malaysia and 60 million in Italy), we thought that the pattern for the COVID-19 in the two territories will be different. The influence of MCO on the spread of the COVID-19 outbreak cannot be ignored. So, it might not be realistic to assume that what is going to happen in Malaysia may soon reflect what happened in Italy. Of course, it would have been more fitting to equate Malaysia (32 
million people) directly with the Lombardy region (9 million people), which is now the most critically affected region in Italy, but sadly these data are not available (JHU, 2020). We do not currently have empirical data that we should consider making more accurate predictions about the number of patients that will be infected in the coming weeks. Based on the available data (See Table 2 ), the number of patients infected in the Malaysian population reached roughly 3561 by $5^{\text {th }}$ April 2020. This is challenging for Malaysia as there are now in the middle of MCO and the order will be ended by $14^{\text {th }}$ April 2020. The aim, for now, is to increase the number of safely meet urgent needs in procuring personnel, technical equipment, beds, laboratories, and materials. For most people, COVID-19 infection will cause mild illness. However, it can make people very ill and, in some people, it can be fatal. Older people and those with pre-existing medical conditions (such as cardiovascular disease, chronic respiratory disease, hypertension, and diabetes) are at risk for severe infection and can be fatal (JHU, 2020).

The high mortality rate is higher in Italy than that observed in other countries (JHU, 2020) could be related to 3 factors (Onder et al., 2020). The first factor is the age of the population, the demographic features of the Italian population vary from those of other countries (Onder et al., 2020). Around $23 \%$ of the Italian population was 65 years of age and older in 2019 and COVID-19 is more lethal in older patients. Hence, Italy's older age distribution may explain a higher case fatality rate compared to other countries' (Onder et al., 2020). The second potential theory may be how deaths due to COVID-19 are reported in Italy. In Italy, case fatality is focused on identifying COVID-19 associated deaths as those occurring in patients who test positive for SARS-CoV-2 via RTPCR, regardless of the underlying medical conditions that may have caused death. This approach was chosen because there are no specific guidelines for identifying COVID-19 associated deaths. Thus, the case fatality rate may have been overestimated in this way (Onder et al., 2020). The third potential cause for variability in case-fatality rates is the different methods used in the testing of SARS-CoV-2 RT-PCR. In Italy, the tests gave priority to patients with more serious clinical symptoms that needed hospitalization and were limited to asymptomatic people or those with minor, mild symptoms. This recommendation for monitoring resulted in a high proportion of positive outcomes and a significant rise in the fatality rate of the case as patients with moderate illness and less serious cases were no longer being tested (Onder et al., 2020). Therefore, certain groups of patients with low fatality levels were no longer included in the denominator.

In addition, the current approach to these patients in Lombardy implies non-pharmacological and pharmacological interventions, including antiretroviral medication which might be different from Malaysia and this could distort the calculation. Malaysia has different testing strategies. For example, Malaysia has adopted widely testing for COVID-19. This can lead to the detection of a significant number of people with mild or restricted symptoms, but a significantly lower fatality 
rate compared to Italy ( $1.4 \%$ vs $11.0 \%)$. This is because many patients with minor illness that should not have been examined in Italy have been included in the Malaysian denominator (Appendix 1). These testing strategies might explain why the case fatality rate in Malaysia is lower than in Italy.

\section{Conclusion}

In fact, Malaysia is better positioned for responding to the current outbreak than many other countries. If the outbreak in Malaysia follows a similar pattern as a linear trend model, the number of newly infected patients could rise by 1000 in a week. Nonetheless, this cannot be expected at present because of the variations between social distance interventions and Malaysia's determination to obey the order of movement regulations. Our trend analysis might help political leaders and health authorities to allocate enough resources including healthcare personnel, hospitals, beds, and laboratories to manage the situation in the next few days and weeks.

It is important to provide general easy guidelines and recommended action plans for prevention and control of Covid-19. This will help to minimize the spread and reduce its impacts among Malaysian and worldwide community. Without an easy and general guideline, it is very hard to reduce the transmission risk of COVID-19 in public, it is very important to strengthen the public health measures and surveillance by giving them an adequate awareness on the prevention and control of Covid-19. Enhancing effective health education includes the SARS-COV-2 (the virus), their mode of transmission, incubation and infectious period, clinical presentation, and high-risk groups. This is the best strategy for the public to prevent, control and mitigate the risk and reduce the impact of Covid-19 in the community.

\section{Acknowledgement}

The authors would like to express their appreciation for providing research funding to Universiti Sains Malaysia (USM) and Taj Din's Pharma Plus (Research Grant No.304/PPSG/6150179/T150).

\section{References}

Anis, M. N. (2020). MCO extended to April 14. The Star. Retrieved from: https://www.thestar.com.my/news/nation/2020/03/25/mco-extended-to-april-14.

CDC. (2020). People who are at higher risk for severe illness of COVID-19. Retrieved from: https://wwwcdcgov/coronavirus/2019-ncov/need-extra-precautions/people-at-higherrisk.html.

Horowitz, J. (2020). Italy announces restrictions over entire country in attempt to halt coronavirus. The New York Times. Retrieved https://www.nytimes.com/2020/03/09/world/europe/italy-lockdown-coronavirus.html.

JHU. (2020). Coronavirus COVID-19 Global Cases. Center for Systems Science and Engineering (CSSE). Retrieved from: https://coronavirus.jhu.edu/. 
Joseph, T., \& Ashkan, M. (2020). International pulmonologist's consensus on Covid-19. Retrieved from: https://www.unah.edu.hn/dmsdocument/9674-consenso-internacional-deneumologos-sobre-covid-19-version-ingles.

Karim, L. A. A. (2020). 190 kes baharu COVID-19, majoriti punca ijtimak tabligh. BH Online. Retrieved from: https://www.bharian.com.my/berita/nasional/2020/03/665578/190-kesbaharu-covid-19-majoriti-punca-ijtimak-tabligh.

MOH. (2020a). Latest statistic of COVID-19 in Malaysia. Retrieved from: http://www.moh.gov.my/index.php/pages/view/2019-ncov-wuhan.

MOH. (2020b). Guidelines on COVID-19 management in Malaysia number 05/2020 (5th Edition). Retrieved March 25, 2020 from: http://wwwmohgovmy/indexphp/pages/view/2019-ncovwuhan-guidelines.

Onder, G., Rezza, G., \& Brusaferro, S. (2020). Case-fatality rate and characteristics of patients dying in relation to COVID-19 in Italy. Jama, 323(18), 1775-1776.

Tang, A. (2020). Malaysia announces movement control order after spike in Covid-19 cases. The Star. Retrieved from: https://www.thestar.com.my/news/nation/2020/03/16/malaysiaannounces-restricted-movement-measure-after-spike-in-covid-19-cases.

van Doremalen, N., Morris, D. H., Holbrook, M. G., ..., \& de Wit, E. (2020). Aerosol and surface stability of SARS-CoV-2 as compared with SARS-CoV-1. The New England Journal of Medicine, 382, 1564-1567. https://doi.org/10.1056/NEJMc2004973.

Vital Surveillances. (2020). The epidemiological characteristics of an outbreak of 2019 novel coronavirus diseases (COVID-19). China CDC Weekly, 2(8), 113-122.

WHO. (2020a). Clinical management of severe acute respiratory infection (SARI) when COVID-19 disease is suspected: interim guidance. Retrieved March 13, 2020 from: https://www.who.int/publications-detail/clinical-management-of-severe-acuterespiratory-infection-when-novel-coronavirus-(ncov)-infection-is-suspected.

WHO. (2020b). Infection prevention and control during health care when novel coronavirus (nCoV) infection is suspected: interim guidance. Retrieved March 19, 2020 from: https://wwwwhoint/publications-detail/infection-prevention-and-control-during-healthcare-when-novel-coronavirus-(ncov)-infection-is-suspected-20200125.

WHO. (2020c). WHO Director-General's opening remarks at the media briefing on COVID-19 - 11 March 2020. Retrieved from: https://www.who.int/dg/speeches/detail/who-directorgeneral-s-opening-remarks-at-the-media-briefing-on-covid-19---11-march-2020.

Worldometers. (2020a). COVID-19 coronavirus pandemic. Retrieved June 14, 2020 from: https://www.worldometers.info/ coronavirus/.

Worldometers. (2020b). Total coronavirus cases in Italy. Retrieved from: https://www.worldometers.info/coronavirus/country/italy/.

Zou, L., Ruan, F., Huang, M., Liang, L., Huang, H., Hong, Z., ... \& Wu, J. (2020). SARS-CoV-2 viral load in upper respiratory specimens of infected patients. New England Journal of Medicine, 382(12), 1177-1179. 


\section{Appendix 1}

Number of infected and death in Malaysia and Italy from January 24th 2020 till April $2^{\text {nd }}, 2020$

\begin{tabular}{|c|c|c|c|c|c|c|c|c|c|c|c|}
\hline Num. & Date & $\begin{array}{c}\text { Malaysia } \\
\text { (Infected) }\end{array}$ & $\begin{array}{c}\text { Malaysia } \\
\text { (Dead) }\end{array}$ & $\begin{array}{c}\text { Italy } \\
\text { (Infected) }\end{array}$ & $\begin{array}{c}\text { Italy } \\
\text { (Dead) }\end{array}$ & Num. & Date & $\begin{array}{c}\text { Malaysia } \\
\text { (Infected) }\end{array}$ & $\begin{array}{c}\text { Malaysia } \\
\text { (Dead) }\end{array}$ & $\begin{array}{c}\text { Italy } \\
\text { (Infected) }\end{array}$ & $\begin{array}{c}\text { Italy } \\
\text { (Dead) }\end{array}$ \\
\hline 1 & 24-Jan-2020 & 3 & 0 & 0 & 0 & 36 & 28-Feb-2020 & 25 & 0 & 888 & 21 \\
\hline 2 & 25-Jan-2020 & 4 & 0 & 0 & 0 & 37 & 29 -Feb-2020 & 29 & 0 & 1128 & 29 \\
\hline 3 & 26-Jan-2020 & 4 & 0 & 0 & 0 & 38 & 01-Mar-2020 & 29 & 0 & 1694 & 34 \\
\hline 4 & 27-Jan-2020 & 6 & 0 & 0 & 0 & 39 & $02-M a r-2020$ & 33 & 0 & 2036 & 52 \\
\hline 5 & 28-Jan-2020 & 8 & 0 & 0 & 0 & 40 & 03-Mar-2020 & 36 & 0 & 2502 & 79 \\
\hline 6 & 29-Jan-2020 & 8 & 0 & 0 & 0 & 41 & 04-Mar-2020 & 50 & 0 & 3089 & 107 \\
\hline 7 & 30-Jan-2020 & 8 & 0 & 0 & 0 & 42 & $05-M a r-2020$ & 55 & 0 & 3858 & 148 \\
\hline 8 & 31-Jan-2020 & 8 & 0 & 2 & 0 & 43 & 06-Mar-2020 & 83 & 0 & 4636 & 197 \\
\hline 9 & 01-Feb-2020 & 8 & 0 & 2 & 0 & 44 & 07-Mar-2020 & 93 & 0 & 5883 & 233 \\
\hline 10 & $02-\mathrm{Feb}-2020$ & 8 & 0 & 2 & 0 & 45 & 08-Mar-2020 & 99 & 0 & 7375 & 366 \\
\hline 11 & 03-Feb-2020 & 9 & 0 & 2 & 0 & 46 & 09-Mar-2020 & 118 & 0 & 9172 & 463 \\
\hline 12 & $04-\mathrm{Feb}-2020$ & 12 & 0 & 2 & 0 & 47 & $10-M a r-2020$ & 130 & 0 & 10149 & 631 \\
\hline 13 & 05-Feb-2020 & 14 & 0 & 2 & 0 & 48 & 11-Mar-2020 & 149 & 0 & 12462 & 827 \\
\hline 14 & $06-F e b-2020$ & 14 & 0 & 3 & 0 & 49 & 12 -Mar-2020 & 158 & 0 & 15113 & 1016 \\
\hline 15 & 07-Feb-2020 & 15 & 0 & 3 & 0 & 50 & 13 -Mar-2020 & 197 & 0 & 17660 & 1266 \\
\hline 16 & $08-\mathrm{Feb}-2020$ & 16 & 0 & 3 & 0 & 51 & 14-Mar-2020 & 238 & 0 & 21157 & 1441 \\
\hline 17 & 09-Feb-2020 & 18 & 0 & 3 & 0 & 52 & 15-Mar-2020 & 428 & 0 & 24747 & 1809 \\
\hline 18 & $10-\mathrm{Feb}-2020$ & 18 & 0 & 3 & 0 & 53 & 16-Mar-2020 & 553 & 0 & 27980 & 2158 \\
\hline 19 & $11-F e b-2020$ & 18 & 0 & 3 & 0 & 54 & 17-Mar-2020 & 673 & 2 & 31506 & 2503 \\
\hline 20 & 12 -Feb- 2020 & 19 & 0 & 3 & 0 & 55 & 18-Mar-2020 & 790 & 2 & 35713 & 2978 \\
\hline 21 & $13-\mathrm{Feb}-2020$ & 19 & 0 & 3 & 0 & 56 & 19-Mar-2020 & 900 & 2 & 41035 & 3405 \\
\hline 22 & 14-Feb-2020 & 21 & 0 & 3 & 0 & 57 & 20-Mar-2020 & 1030 & 3 & 47021 & 4032 \\
\hline 23 & $15-\mathrm{Feb}-2020$ & 21 & 0 & 3 & 0 & 58 & 21-Mar-2020 & 1183 & 8 & 53578 & 4825 \\
\hline 24 & $16-\mathrm{Feb}-2020$ & 22 & 0 & 3 & 0 & 59 & 22-Mar-2020 & 1306 & 11 & 59138 & 5475 \\
\hline 25 & 17-Feb-2020 & 22 & 0 & 3 & 0 & 60 & 23-Mar-2020 & 1518 & 14 & 63927 & 6077 \\
\hline 26 & 18 -Feb-2020 & 22 & 0 & 3 & 0 & 61 & 24-Mar-2020 & 1624 & 16 & 69176 & 6820 \\
\hline 27 & $19-\mathrm{Feb}-2020$ & 22 & 0 & 3 & 0 & 62 & $25-M a r-2020$ & 1796 & 20 & 74386 & 7503 \\
\hline 28 & 20 -Feb-2020 & 22 & 0 & 3 & 0 & 63 & 26-Mar-2020 & 2031 & 24 & 80589 & 8215 \\
\hline 29 & 21-Feb-2020 & 22 & 0 & 20 & 1 & 64 & 27-Mar-2020 & 2161 & 26 & 86498 & 9134 \\
\hline 30 & 22-Feb-2020 & 22 & 0 & 79 & 2 & 65 & 28-Mar-2020 & 2320 & 27 & 92472 & 10023 \\
\hline 31 & 23 -Feb-2020 & 22 & 0 & 155 & 3 & 66 & 29-Mar-2020 & 2470 & 34 & 97689 & 10779 \\
\hline 32 & 24-Feb-2020 & 22 & 0 & 229 & 6 & 67 & 30-Mar-2020 & 2626 & 37 & 101739 & 11591 \\
\hline 33 & $25-\mathrm{Feb}-2020$ & 22 & 0 & 322 & 10 & 68 & 31-April-2020 & 2766 & 43 & 105792 & 12428 \\
\hline 34 & 26-Feb-2020 & 22 & 0 & 445 & 12 & 69 & 01-April-2020 & 2908 & 45 & 110574 & 13155 \\
\hline 35 & $27-\mathrm{Feb}-2020$ & 24 & 0 & 650 & 17 & 70 & 02-April-2020 & 3116 & 50 & 115242 & 13915 \\
\hline
\end{tabular}

Malaysian and Italian trend line for Covid-19... (Wan Ahmad et al.) 
BAMME Vol. 1 No. 2, October 2021, pp. 61-74

This page is intentionally left blank. 